\title{
Boka Kotorska: društveno-političke promjene i razvoj etničkog sastava do 1918. godine
}

\author{
Ivan Crkvenčić, Antun Schaller
}

\begin{abstract}
Boka kotorska je prostran i razgranat zaljev u južnom dijelu istočne obale Jadranskog mora. Teritorijalno pripada Crnoj Gori, koja je politički u sastavu Državne zajednice Srbije i Crne Gore, a nalazi se neposredno uz granicu s Republikom Hrvatskom. Ističe se kao specifična prirodna cjelina, obilježena vrlo složenim društvenim razvojem i etničkim promjenama. Unatoč tome, Boka kotorska prepoznatljiva je po svojem jedinstvenom kulturnom pejzažu, nastalom za vrijeme stoljećima dugog razvoja.
\end{abstract}

Ključne riječi: Prirodna obilježja, razdoblja društveno-političkih promjena, razvoj etničkog sastava, naseljenost i naselja

\section{Boka Kotorska (The Bay of Kotor): Social and Political Changes and Development of Ethnic Structure up to 1918}

Boka Kotorska is a relatively large and well-indented bay lying at south of the east Adriatic coast. In political sense it is part of Montenegro, one of two republics composing the State Union of Serbia and Montenegro. Boka Kotorska is situated immediately at the state border to the Republic of Croatia. It is a specific geographical entity, characterised by a very complex process of social development and consequent ethnic changes. In spite of that, Boka Kotorska is recognisable by its unique cultural landscape, which has been formed during centuries of its abundant history.

Key words: Physical characteristics, periods of social and political changes, development of ethnic structure, settlements

\section{PREGLED PRIRODNIH OBILJEŽJA}

Boka Kotorska (u daljnjem tekstu: Boka) je prostran zaljev na obali Jadranskog mora, oko 15 km uvučen u kršku kopnenu unutrašnjost. Od otvorenog mora odvojena je nizom poluotoka (visokih do 789 m) - Vrmcem, Lušticom i Devesiljem - dok se prema kopnenoj unutrašnjosti strmo izdiže i prelazi u planine Orjen $(1.895 \mathrm{~m})$ i Lovćen $(1.749 \mathrm{~m})$.

Boka je složena od dva izdužena zaljeva: vanjskog, Hercegnovsko-tivatskog, i unutrašnjeg, Risansko- kotorskog zaljeva. Oba zaljeva međusobno su povezana tjesnacem zvanim Verige $^{1}$, čija širina iznosi $340 \mathrm{~m}$. Plovna duljina od ulaska u Boku do grada Kotora u krajnjoj unutrašnjosti zaljeva, iznosi oko $30 \mathrm{~km}$. Najveća dubina mora u Boki izmjerena je u njegovom unutrašnjem dijelu, a iznosi $47 \mathrm{~m}$. 


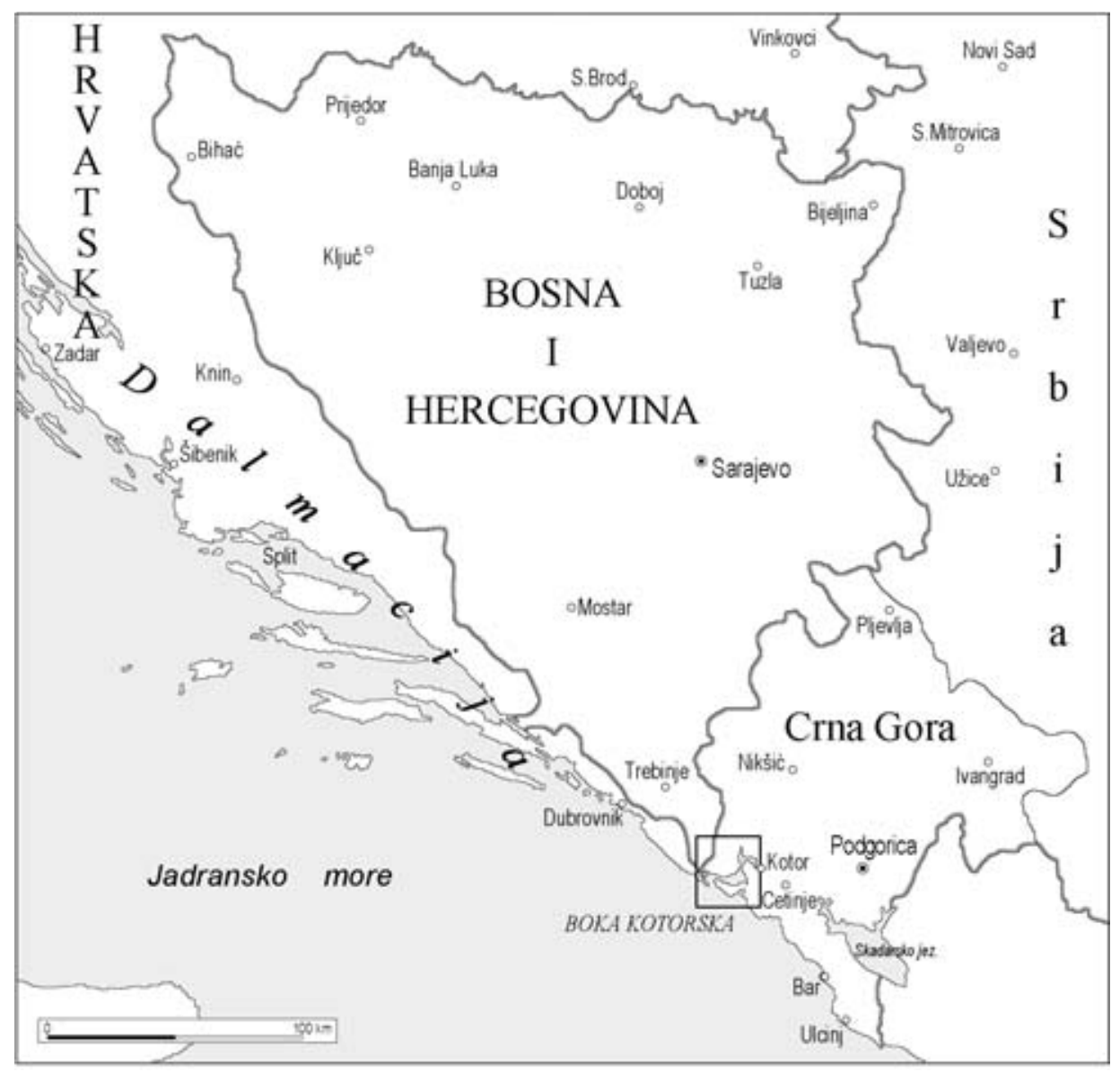

S1. 1. Položaj Boka Kotorske na istočnoj obali Jadranskog mora

Fig. 1 Position of the Boka Kotorska (Bay of Kotor) on the east coast of the Adriatic Sea

Zaljevi Boke Kotorske nastali su za vrijeme glacijacije riječnom erozijom u mekšim flišnim stijenama, dok su reljefno više strane zaljeva izgrađene od otpornijih stijena, pretežno trijaskih vapnenaca i dolomita. Kada se u postglacijalnom razdoblju površina mora podigla za oko $100 \mathrm{~m}$, erozijom prethodno stvorene doline su potopljene i pretvorene u zaljeve. Reljef je dodatno modificiran djelovanjem krških procesa, a na višim padinama podno Orjena i djelovanjem ledenih jezika koji su se spuštali niz padine te planine. Istovremeno je Lovćen bio pokriven sniježnim pokrovom (Riđanović, J., 1990, 1993).

Kopnene strane Boke su vrlo strme (nagibi općenito veći od 25²), a na visine do 200 $\mathrm{m}$ nad morem otpada tek trećina kopnenih strana zaljeva. Goli vapnenački grebeni dižu se, dakle, naglo i strmo, osobito iznad unutrašnjeg zaljeva. Planine Orjen i Lovćen na sjevernom i istočnom rubu Boke ističu se kao čuvari ove rijetke ljepote nad cijelim krajem. Zone mekšeg materijala, odnosno fliša, zauzimaju manje površine i glavna su područja 
uglavnom škrte vegetacije. Blago nagnuta i vegetacijom donekle pokrivena flišna područja prava su suprotnost divljim i pustim vapnenačkim hridinama (Roglić, J., 1967).

Boka se nalazi u području prevladavajuće jadransko-mediteranske klime s toplim i suhim ljetima, a blagim i vlažnijim zimama. Srednja temperatura siječnja, kao najhladnijeg mjeseca, u Herceg Novom iznosi $8,2^{\circ} \mathrm{C}$, dok je srednja temperatura najtoplijeg mjeseca, srpnja, $24,3^{\circ} \mathrm{C}$. Količina padalina u priobalju lokalno varira od oko $1.830 \mathrm{~mm}$ (kod Herceg Novog) do $2.930 \mathrm{~mm}$ (kod Risna). No, planinska unutrašnjost padalinama je znatno bogatija, tako da u Crkvicama (u sjeverozapadnom zaleđu Boke) godišnje padne čak do $5.000 \mathrm{~mm}$ vodenog taloga, što je najveća količina izmjerena u Europi. Međutim, usprkos znatnim količinama padalina, područje Boke oskudijeva vodom, naročito ljeti; padaline, naime, podzemno nestaju kroz vapnenačku podlogu. Dijelom se ta voda javlja na površini u obliku vrela, naročito u područjima fliša.

Pretežno gole vapnenačke strane Boke imaju malu gospodarsku vrijednost, a i to samo u zonama u kojima prevladava dolomit ili relativno starije flišovite stijene (najviše u zaleđu Herceg Novog). Za ratarstvo je najpogodniji uzak pojas fliša, koji je najzastupljeniji u dodirnom području priobalja i rubova kopnenih padina. Glavne ratarske kulture su maslina, vinova loza i agrumi. Međutim, taj obradivi pojas isuviše je malen da bi mogao osigurati život brojnim stanovnicima razmatranog prostora. Istovremeno su strme vapnenačke stijene na stranama zaljeva i visoke planine u zaleđu odvajale stanovnike Boke od zaleđa, te ih od najranijih vremena upućivale na more preko kojeg su tražili izvore života.

\section{PREDUVJETI DRUŠTVENOG RAZVOJA BOKE KOTORSKE}

O društvenom razvoju Boke Kotorske može se govoriti kao o svojevrsnom mozaiku nekoliko karakterističnih razdoblja, koja su u kulturnom pejzažu kraja ostavila tragove svoje materijalne i duhovne kulture. Takav njen složen razvoj poglavito je posljedica sljedećih činjenica:

1. posebnosti oblika i prirodnih obilježja prostora,

2. geopolitičkog položaja na južnom dijelu istočne obale Jadrana koja je dugo vremena bila izložena političkim utjecajima s morske strane, ali i iz zaleđa,

3. položaja Boke u čijem je zaleđu bilo kontaktno područje raširenja katoličke i pravoslavne vjeroispovijesti, a time, kasnije, hrvatskog i srpskog, odnosno, crnogorskog etničkog teritorija i

4. prodora Osmanlija u 15. stoljeću u zaleđe Boke, koji je uzrokovao velika stradanja i migracije domaćeg stanovništva te širenje islama, naročito na račun katoličke vjere.

Navedene činjenice utjecale su na vrlo bogatu i složenu političku prošlost Boke, kakvu je, uostalom, imalo i čitavo pročelje istočne obale Jadrana, odnosno, susjedna Dalmacija, koja je od 7. stoljeća etničko područje Hrvata. Stoga će u ovom prilogu biti prikazani samo oni elementi iz prošlosti Boke koji ukazuju na njezine vanjskopolitičke veze i koji su utjecali na karakter etničkog sastava stanovništva Boke. 


\section{PREDVENECIJANSKO RAZDOBLJE}

Nakon manje poznatog ilirskog razdoblja, kada je naselje Risan u unutrašnjem dijelu zaljeva, bio i sjedište Ilira, slijedilo je dugo razdoblje rimske vlasti (od 168. g. pr. Krista do 476.g.) za koje je Boka bila podčinjena konventu Narone i, kao dio Salonitansko-splitske metropolije, povezana s Dalmacijom. Upravno središte Boke je preseljeno iz razorenog Risna u Decaderon ili Catharum, grad na mjestu današnjeg Kotora. Od tog vremena zaljev se više ne naziva Risanski zaljev (lat. Sinus Rhizonikos), već Kotorski zaljev (Sinus Catharensis) (Marinović, A., 1993).

U razdoblju rimske vladavine izvršena je asimilacija starosjedilačkog ilirskog stanovništva i uvedeno kršćanstvo. Romansko i romanizirano stanovništvo gradova Boke, ali i njenih drugih naselja, temelj je latinske kulture, koja je dominirala u Boki i nakon doseljavanja slavenskog stanovništva (Macan, T., 1993).

Krajem 6. stoljeća Boka, kao uostalom i veći dio istočne jadranske obale, ulazi u sastav Bizanta, u kojemu ostaje do 12. stoljeća. Kotor (Decaderon), kao glavno središte Boke, postaje autonomni bizantski municipij, koji se u razdoblju 5.-7. stoljeća nalazi u sastavu Dalmatinskog temata sa sjedištem u Zadru. Bizantska se uprava uglavnom ograničava na utvrđene gradove, dok je zaleđe Boke u vlasti novih slavenskih političkih cjelina - Travunje sa središtem u sjeverozapadnom i Duklje, sa sjedištem u jugoistočnom zaleđu Boke (Butorac, P., 1963).

U 7. stoljeću dolaze Slaveni, pa se etnički sastav prostora počinje mijenjati, i to ne samo u područjima izvan gradova, već postupno i u samim gradovima. Prethodno romansko i romanizirano stanovništvo djelomice je izginulo, dijelom se iselilo ili se povuklo u gradove, naročito u Kotor. No, u 10. stoljeću proces slavenizacije zahvaća i do tada romansko stanovništvo Kotora (Marinović, A., 1993).

U ranom srednjem vijeku stanovništvo Kotora etnički se razlikovalo od stanovništva ostalog dijela Boke. Gradsko stanovništvo, poglavito stanovništvo Kotora, uglavnom je romansko, dok u okolnim naseljima prevladava slavensko stanovništvo. Sredinom 15. stoljeća u Kotoru još uvijek živi oko stotinu vlastelinskih obitelji, uglavnom staroromanskog i staroslavenskog, odnosno hrvatskog podrijetla (Sindik, I., 1950). Procesom asimilacije slavensko je stanovništvo postupno prevladalo i u gradovima.

Iz nekih povijesnih podataka proizlazi da je, bez obzira na vladavinu Bizanta, Boka u razdoblju od 8. do 10. stoljeća bila u sastavu tzv. Crvene Hrvatske ('Croatia Rubea'). O tome govori ne samo Pop Dukljanin, već i nekoliko bizantskih izvora (Porfirogenet, Scylitzes, Cedrenus, Choniates, Zonaras). Odatle je izveden i zaključak da su među doseljenim slavenskim plemenima u tom prostoru Hrvati bili dominantna etnička skupina (Štedimlija, S.M., 1991).

Unatoč formiranju spomenutih političkih cjelina (Travunje i Duklje), Kotor s okolicom ostaje samostalna komuna i sjedište katoličke biskupije. Iz vremena bizantske vladavine potječe i kotorska katolička katedrala sv. Tripuna, koja je početkom 12. st. podignuta na mjestu jedne starije katoličke crkve (vjerojatno iz 9. stoljeća) i smatra se najstarijom katedralnom crkvom na istočnoj obali Jadrana (Marinović, A., 1993). 
Nakon razdoblja bizantske uprave slijedi razdoblje u kojemu se u Boki mijenjala vlast zemalja iz njenog kopnenog zaleđa. Bokom prvo vladaju Nemanjići (1185.-1371. g.), kojima Kotor služi kao važna tranzitna luka. Kroz cijeli period vlasti Nemanjića Kotor zadržava visok stupanj samouprave. Nakon Nemanjića Bokom zavlada ugarsko-hrvatski kralj Ljudevit I. Veliki (1371.-1382. g.) koji nakon pobjede nad Venecijom vlada gotovo cijelom istočnom obalom Jadranskog mora. Nakon Ljudevitove smrti Boka kraće vrijeme (1384.-1391. g.) dolazi u posjed srednjevjekovnog bosanskog kraljevstva kojim upravlja kralj Stjepan Tvrtko I. Kotromanić. Tvrtko na krajnjem zapadnom dijelu Boke gradi novi grad - Herceg Novi, koji mu je bio potreban kao tranzitna luka. Poslije Tvrtkove smrti Bosna gubi političku snagu, pa Boka ulazi u svojevrsni politički vakuum i u Kotoru se uspostavlja samostalna uprava (tzv. 'Tempore Catharinorum') (Marinović, A., 1993).

No, zbog osvajačkih težnji država u kopnenom zaleđu (Zete i Raške), Kotor 1395. g. prvi put traži pokroviteljstvo Venecije, što ona odbije. Potom, Kotor 1403. g. prihvaća protektorat Anžuvinca Ladislava Napuljskog, koji je tada vladao i Hrvatskom. Međutim, Vladislav 1409. g. svoje pravo na Dalmaciju prodaje Veneciji, pa Kotor opet traži pokroviteljstvo Venecije koje ona 1420. g. konačno prihvaća. Tako je Boka, zajedno s Dalmacijom, došla pod istu vlast - vlast Venecije (Marinović, A., 1993).

\section{VENECIJANSKO-TURSKO RAZDOBLJE}

Venecija vlada Bokom od 1420. do 1797. g., dakle, gotovo četiri stoljeća. To je vrijeme gospodarskog napretka Boke, karakteriziranog napuštanjem tradicionalne poljoprivrede i sve jačim razvojem brodarstva, pomorstva i pomorske trgovine. Vrlo razvijenom trgovačkom flotom Boka je uspostavila trgovačke odnose s mnogim mediteranskim, pa i atlantskim zemljama. To je doba jedrenjaka, koji su bili temelj bokeljske trgovačke moći ${ }^{2}$.

Kotor, do tada najvažnije naselje u Boki, u venecijanskom razdoblju, a naročito od 16.stoljeća, postupno gubi na važnosti, tako da mu preostaju samo funkcije središta mletačke vlasti. Težište gospodarskog razvoja, posebno razvoja pomorstva i pomorske trgovine, iz Kotora prelazi u do tada gospodarski manje razvijena mjesta, prije svega u Perast, Prčanj i Dobrotu (Marinović, A., 1993).

U doba pomorskog prosperiteta Boke veću je važnost imao unutrašnji Risanskokotorski zaljev, u kojemu su naselja Kotor, Perast, Dobrota, Prčanj i Stoliv slovila kao stara pomorska 'gnijezda', poznata po brojnim kapetanskim obiteljima: Dabčevićima, Đurovićima, Florijima, Gojkovićima, Kamenarovićima, Lazarima, Lučićima, Milinima, Miloševićima, Nikolićima, Radoničićima, Tripkovićima, Veronama, Visinima, Vojnovićima, Vučetićima i drugima. Treba naglasiti da su nositelji pomorstva i pomorske trgovine u Boki bile slavenske obitelji, i to najviše one, hrvatske narodnosti.

Međutim, spomenuti gospodarski razvoj nije bio stalan, niti je zahvatio sve dijelove Boke. Razlog tome bili su Turci, koji krajem 15. stoljeća prodiru u široko područje kopnenog zaleđa, pa i u područje same Boke.

Nakon što je 1483. g. bosanski vladar Vlatko Hercegović Kosača bio prisiljen Turcima predati svoje dvije posljednje utvrde i posjede u sjeverozapadnom dijelu Boke, između 
Herceg Novog i Risna (koje je zadržao bez obzira što je u međuvremenu najveći dio Boke došao pod mletačku vlast), Boka je sljedećih više od 200 godina politički podijeljena između Venecije u svojem jugoistočnom i Turske u sjeverozapadnom dijelu. Nakon što su osvojili šire hercegnovsko područje, Turci uskoro šire svoju vlast na naselja Morinj i Risan, okolicu Perasta (ali ne i sam grad!) te gotovo na čitav sjeverni dio Boke do naselja Orahovac i Župu (Grbalj), jugoistočno od Kotora (Macan, T., 1993).

Razgraničenje venecijanskih i turskih posjeda u Boki konačno je uspostavljeno duž crte koja je vodenim, odnosno, morskim dijelom zaljeva išla od rta Kobile preko tjesnaca Verige do naselja Orahovac, dakle sredinom akvatorija zaljeva. Prostor sjeverozapadno od spomenute crte došao je pod vlast Turaka, dok je područje na jugoistoku od nje ostao u vlasti Venecije.

Kao što će kasnije biti prikazano, dolazak Turaka na obale Boke i razgraničenje bokeljskog prostora između dviju snažnih vojno-političkih cjelina onog vremena, imalo je velik utjecaj na daljnji razvoj etničke strukture Boke.

Povratak teritorija Boke zaposjednutih od Turaka pod vlast Venecije započeo je krajem 17. stoljeća, Morejskim ratom (1684.-1699.). Venecija vraća cjelokupno šire područje Boke pod svoju upravu 1687. g., osvajanjem Herceg Novog (Marinović, A., 1993).

Povlačenjem Turaka iz područja Boke i uspostavljanjem političke stabilnosti već prije spomenuti gospodarski razvoj pomorstva i pomorske trgovine Boke se nastavio. Sredinom 18. stoljeća primorska naselja zaljeva već su napustila prijašnje bavljenje zemljoradnjom te se posve posvetila trgovini i pomorstvu.

No, nakon kraćeg mirnog razdoblja u Europi, pa tako i u Boki, dolazi do političke nesigurnosti, uvjetovane napoleonskim ratovima. Venecija propada 1797. g., pa je Boka kraće vrijeme u vlasti Austrije (1797.-1806. g.), Rusije (1806.-1807.g.) i Francuske (1807.1813.g.), a nepunu godinu dana (1813.-1814.g.) u Boki djeluje zajednička crnogorskobokeljska uprava (Marinović, A., 1993).

U vrijeme napoleonskih ratova bokeljska trgovačka mornarica je propala. Za nepuna dva desetljeća bokeljska flota je gotovo nestala, tako da je broj velikih brodova s $395 \mathrm{u}$ 1805. g., do 1814. g. smanjen na svega 53 broda duge plovidbe (Primožić, A., 1942).

Nekadašnji gospodarski prosperitet postupno se pretvarao u gospodarsko siromašenje Boke. Svjedoci nekadašnjeg bogatstva Perasta, Prčanja i Dobrote su preostale monumentalne palače i crkve od kojih su mnoge opustjele i ruševne.

\section{RAZDOBLJE AUSTRIJSKE UPRAVE (1814.-1918. g.)}

Od 1814.g. Austrija, kao nasljednik nekadašnjih posjeda Venecije, uspostavlja Kraljevinu Dalmaciju sa sjedištem u Zadru, a u sastavu Dalmacije je i Boka. Vlast Austrije nad Dalmacijom, a time i Bokom, traje cijelo jedno stoljeće, odnosno do propasti Habsburške monarhije 1918.g.

U političkom i geografskom smislu Boka, iako austrijski posjed, sve do aneksije Bosne i Hercegovine (1906. g.), predstavlja svojevrsni ‘corpus separatum'. Ona je, naime, 
od ostalog dijela austrijske Dalmacije bila odijeljena uskim primorskim pojasom Sutorine koji je jednako kao područje Neuma na zapadnoj granici bivše Dubrovačke Republike) i dalje ostao u vlasti Turske.

Austrijsko razdoblje vladanja karakterizira gospodarsko nazadovanje Boke, uvjetovano prije svega globalnim promjenama u pomorstvu, dakle upravo u onoj gospodarskoj grani na kojoj je Boka stoljećima temeljila svoj procvat. Doba jedrenjaka, tog simbola bokeljskog pomorstva zauvijek je, naime, prošlo, a za značajnije uvođenje nove pomorske prometne inovacije, tj. parobroda u vlastitu pomorsku trgovinu, sama Boka gospodarski nije bila sposobna, a niti se parobrodarstvo moglo uvesti zbog političkih razloga. Promijenili su se i globalni odnosi u pomorstvu. Već na prijelazu iz 17. u 18. stoljeće pomorska trgovina se sve više koncentrira u velikim lukama bliže gospodarski razvijenim zemljama Europe, dakle u Trstu i u Rijeci. Taj je proces konačno završen uvođenjem parobroda u pomorski promet. Zbog osobitosti svog geostrateškog položaja na krajnjem jugu austrijskog državnog teritorija, Austrija je Boku u drugoj polovici 19. stoljeća odabrala za veliku ratnu luku svoje ratne mornarice, odnosno za vojno-strateško središte obrane Austrougarske monarhije.

Gotovo da na bokeljskim obalama tada nije bilo naselja koje nije imalo neko vojno značenje i koje nije bilo opskrbljeno nekim objektom vojne infrastrukture. To se u velikoj mjeri odrazilo i na sastav stanovništva u kojemu su značajan udjel imali strani državljani. Austrija u Boki gradi utvrde, a u Tivtu i arsenal za potrebe svoje ratne ratne mornarice. Na taj je način potaknut razvoj Tivta, do tada malog naselja Crni Plat.

Zbog strateških je potreba 1901. g. izgrađen i nastavak uskotračne željezničke pruge Sarajevo-Dubrovnik, i to između Dubrovnika i Zelenike, tada malog naselja nedaleko Herceg Novog, na obali vanjskog zaljeva Boke. Izgradnjom Tivta, a sada i te pruge, ojačana je važnost vanjskog, Hercegnovsko-tivatskog zaljeva. To se u značajnoj mjeri odrazilo i na brži razvoj drugih naselja tog dijela Boke. Međutim, kao što je već rečeno, istovremeno je gospodarski počeo zaostajati unutrašnji dio Boke, dakle, Risansko-kotorski zaljev.

Austrija u upravu uvodi nove institucije u skladu sa suvremenim napretkom u Europi. Jedan od tih je ustroj zemljišnog katastra koji je osnova oporezivanja, ali ujedno i pretpostavka rješavanja zemljišno-pravnih odnosa, pa i značajna osnova suvremene statistike. Geodetska snimanja su u Boki obavljena u razdoblju 1824.-1838. g. (Piplović, S., 2003), čime je taj prostor dobio solidnu podlogu za uvođenje i drugih elemenata suvremene administracije.

U vrijeme venecijanske vlasti u u Dalmaciji pa ni u Boki, nije bilo neke stalne administrativne teritorijalne podjele. Izdvajali su se gradovi, kojima je pripadao određeni prostor, i općine. Gradovi su imali svoje statute, posebna prava i privilegije.

Venecijanski posjedi na istočnoj obali Jadrana, dakle u Dalmaciji, pa i u Boki, svoje su konačne granice dobili nakon Požarevačkog mira 1718. g., dok je jedinstvena administrativna uprava (po distriktima, kantonima i općinama) uspostavljena tek 1806. g., odnosno u vrijeme prve austrijske uprave u Boki. Dalmacija je tada podijeljena u 4 okružja, među kojima i okružje Boka koja je imala tri distrikta sa središtima u Kotoru, Herceg Novom i Budvi, a nešto kasnije i u Risnu. Konačno je austrijska Dalmacija, zajedno s Bokom, podijeljena u 13 kotara, među kojima je i kotar Kotor (Maschek, A., 1888). 
Navedenom teritorijalnom organizacijom stvoreni su uvjeti za provođenje suvremenih popisa stanovništva i uvođenje novih gospodarskih elemenata. Takvi suvremeni popisi u Boki su provedeni tek u drugoj polovici 19. stoljeća.

\section{RAZVOJ ETNIČKOG SASTAVA BOKE}

Navedene česte društvene i političke promjene očito su bile značajne za razvoj stanovništva Boke, posebno na njegov etnički sastav. To se, prije svega, očitovalo kroz procese asimilacije, ali i migracije stanovništva. U nastavku slijedi nekoliko poznatijih (ili barem vrlo vjerojatno dogođenih) primjera takvih procesa.

U vrijeme rimske vlasti provedena je asimilacija starosjedilačkog ilirskog stanovništva od strane Rimljana, dok su kasnije, nakon dolaska u ova područja Slaveni asimilirali zatečeno romansko ili romanizirano stanovništvo. Određen utjecaj imala je i dugotrajna vladavina Venecije, u vrijeme koje je u Boki kod slavenskog stanovništva, poglavito hrvatskog, došlo do stvaranja plemićkog sloja, naročito u gradovima.

Ipak, najjači je utjecaj na etničke promjene stanovništva Boke imala već opisana turska okupacija dijela Boke. U tom pogledu naročito je do izražaja došlo već opisano razgraničenje Boke na tursko i venecijansko područje vladanja, i to crtom koja je išla od rta Kobile sredinom vodenog dijela zaljeva do naselja Orahovac na sjeveroistoku unutrašnjeg, Risansko-kotorskog zaljeva.

Uvenecijanskom dijelu Boke bilo je područje Dobrotskog primorja s gradom Kotorom i Škaljarima, poluotok Vrmac, istočna obala Tivatskog zaljeva s područjem naselja Tivat i naseljima u prevlaci Krtole te naselja na poluotoku Luštica. Sjeverozapadno od spomenute crte, unutar područja pod vlašću Turaka, kao venecijanske enklave ostala su naselja Perast, Strp i Lipci u Risanskom zaljevu, naselje Kostanjica u Morinjskom zaljevu te naselje Đurići uz tjesnac Verige. Za razliku od njih, naselja Risan, Morinj i Jošica kao i sva naselja od naselja Bijela do Herceg Novog bila su pod vlašću Turaka.

Navedena podjela trajala je sve do 1687. g., kad je Venecija pod svoju upravu uspjela vratiti sva spomenuta naselja koja su bila pod turskom vlašću. Jedino je područje Grblja, kao dijela Boke u širem smislu, Veneciji vraćen tek 1725. g. (Marinović, A., 1993).

Navedeno razgraničenje Boke na venecijanske i turske posjede između 15. i 17. stoljeću predstavljalo je ne samo veliku prepreku neometanom gospodarskom razvoju Boke, već je ostavilo i dugoročne posljedice na konfesionalni, a kasnije i na narodnosni sastav stanovništva Boke. Turska vlast rezultirala je, naime, širenjem pravoslavlja u, do tada, pretežno katoličko područje. Razlog tome je neposredno doseljavanje pravoslavnog stanovništva iz zaleđa koje je bilo pod vlašću Turaka. Poznato je da je iz područja koja su bila ugrožena, a potom i od Turaka okupirana, starosjedilačko katoličko stanovništvo u hrvatskim područjima ili stradalo ili je izbjeglo, a na njihova mjesta Turci su doseljavali pravoslavno stanovništvo (Crkvenčić., I., Pepeonik, Z., 1996; Crkvenčić, I., 2000). Takav se proces mogao odvijati i ovdje, u Boki. Drugi razlog širenja pravoslavlja na račun katolika bio je tolerantniji odnos Turaka prema pravoslavlju, nego prema katolicima. Uzrok blagonaklonosti Turaka prema pravoslavlju treba tražiti u činjenici što je Pećka 
patrijaršija, kao duhovni predstavnik poražene i osvojene srednjovjekovne srpske države, priznala lojalnost Sultanu. Iz tog je razloga kršćanima pod turskom upravom, ako već nisu bili spremni preći na islam, bilo daleko lakše ispovijedati pravoslavnu nego katoličku vjeru. Stoga se može pretpostaviti da su i katolički starosjedioci Boke, ukoliko nisu stradali ili pred Turcima pobjegli, a da bi sačuvali svoje kršćanstvo, dijelom prešli na pravoslavnu vjeru. Budući da je konfesionalno opredjeljenje u to doba bilo od velikog značenja za proces kasnije etnogeneze, može se pretpostaviti da je katoličko stanovništvo koje je u opisanim okolnostima prihvatilo pravoslavlje, kasnije postupno prihvatilo i srpsku, odnosno crnogorsku, narodnost.

Navedena tumačenja o promjeni etničkog sastava Boke nalaze najbolju potvrdu u činjenici što se u svim popisima stanovništva Boke tijekom 19. i20. stoljeća uočava vjerskonarodnosna podvojenost $u$ kojoj se jasno održavaju posljedice već opisanog venecijanskoturskog prostornim razgraničenja Boke. Tako su u dijelu Boke koji je za turskih osvajanja ostao pod vlašću Venecije (Perast, Dobrotsko primorje, Kotor s neposrednom okolicom, poluotok Vrmac, tadašnje venecijanske enklave Strp, Lipci i Kostanjica u Risanskom zaljevu, Đurići na obali tjesnaca Verige) sve do najnovijeg doba brojčano prevladavali katolici, odnosno Hrvati. Suprotno tome, u ostalim područjima Boke (hercegnovsko područje, većina naselja u Risanskom zaljevu, Orahovac, Grbalj) brojčano su prevladavali, a i danas prevladavaju, pravoslavci, odnosno Srbi ili Crnogorci.

Na promjene etničkog sastava Boke utjecala je i Venecija. U borbama s Turcima važnu su ulogu igrali i hajduci, i to kao oblik narodnog otpora protiv Turaka. Njih je Venecija pozivala u područje svoje uprave. Tako se nekoliko stotina hajdučkog stanovništvo naselilou Perastu i Stolivu. Nakon povlačenja Turaka iz Boke velik broj hajduka, koji su pretežno bili pravoslavne vjere, naselio se u području između Herceg Novog i Risna (Rendić-Miočević, I., 2003). S povlačenjem Turaka, to je područje napustilo i muslimansko stanovništvo.

Tab. 1. Površine, broj stanovnika i gustoća naseljenosti Boke kotorske 1900. g.

Tab. 1. Areas, population number and density of the Boka Kotorska (Bay of Kotor) in 1900

\begin{tabular}{|c|c|c|c|c|c|c|c|c|c|c|c|}
\hline \multirow{2}{*}{$\begin{array}{l}\text { Porezni } \\
\text { kotari }\end{array}$} & \multicolumn{2}{|c|}{$\begin{array}{r}\text { Ukupna } \\
\text { površina }\end{array}$} & \multicolumn{4}{|c|}{$\begin{array}{c}\text { Obradive površine } \\
\text { ukupno (ha) }\end{array}$} & \multicolumn{2}{|c|}{$\begin{array}{c}\text { Ostale } \\
\text { površine (ha) }\end{array}$} & \multirow{2}{*}{$\begin{array}{c}\text { Broj } \\
\text { stano- } \\
\text { vnika }\end{array}$} & \multicolumn{2}{|c|}{$\begin{array}{r}\text { Gustoća } \\
\left(\mathbf{s t} . / \mathbf{k m}^{2}\right)\end{array}$} \\
\hline & I. & II. & $\mathbf{a}$ & b & c & d & e & f & & opća & agrarna \\
\hline $\begin{array}{l}\text { Herceg } \\
\text { Novi }\end{array}$ & 132,59 & 127,35 & 932 & 23 & 1.501 & 521 & 5.192 & 4.556 & 9.615 & 72,3 & 320,5 \\
\hline Kotor $^{1}$ & 102,77 & 99,06 & 1.050 & 7 & 1.032 & 386 & 4.743 & 2.706 & 11.127 & 108,0 & 445,1 \\
\hline Risan & 191,77 & 189,83 & 614 & 265 & 280 & 33 & 10.052 & 7.739 & 5.441 & 28,3 & 454,4 \\
\hline Ukupno & 427,13 & 416,14 & 2.596 & 295 & 2.813 & 940 & 19.987 & 15.002 & 26.183 & 61,3 & 396,7 \\
\hline Udio (\%) & - & 100,00 & 6,2 & 0,7 & 6,7 & 2,3 & 48,0 & 36,1 & & & \\
\hline
\end{tabular}

Izvor: Gemeindeleksikon von Dalmatien, Wien, 1908.

${ }^{1}$ bez općine Grbalj

Tumač oznaka i kratica:

I. = sveukupna površina

II. = površine podložne oporezivanju

Obradive površine: $\mathrm{a}=$ oranice, $\mathrm{b}=$ livade, $\mathrm{c}=$ vrtovi, $\mathrm{d}=$ vinogradi

Ostale površine: $\mathrm{e}=$ pašnjaci, $\mathrm{f}=$ šume 
Očito da je bilo i spontanog doseljavanja. Zaleđe Boke vršilo je ulogu biološkog rezervata iz kojeg su se pojedine obitelji spuštale u Boku, u kojoj su uvjeti života bili raznovrsniji i povoljniji nego u njenom zaleđu. No, ti su se došljaci asimilirali s domaćim stanovništvom, i to većinom već u prvoj generaciji. Ovdje treba spomenuti i postupno doseljavanje pravoslavnog stanovništva iz područja nekadašnje turske okupacije (Grbalj i Budvansko primorje) u okolicu Kotora, tj. Krtole (krtola = krumpir) i na poluotok Lušticu.

Treba reći da su prirodni preduvjeti bili glavni regulator doseljavanja. Unatoč dosta niske opće gustoće naseljenosti, agrarna gustoća (u ovom slučaju to je broj ukupnog stanovništva na jedinici obradivih površina) je bila vrlo visoka, tako da je Boka uistinu bila prenaseljena. U razdoblju prevladavanja poljoprivredne proizvodnje u Boki su se koristili svi prostori pogodni za zemljoradnju. (tab. 1). Na nekadašnju poljoprivrednu djelatnost upućuju u pejzažu zaostale terase nekad obrađivanog zemljišta. Naseljavanje je, dakle, bilo uvjetovano i mogućnošću iskorištavanja zemljišta. Može se reći da je atraktivnost mora, naročito u vrijeme prevladavanja pomorskog gospodarenja, bila glavni čimbenik zadržavanja stanovništva.

S propašću pomorske privrede domaće stanovništvo počinje iseljavati, naročito iz pomorskih naselja u unutrašnjem zaljevu, pretežno naseljenom katolicima, najvećim dijelom Hrvatima. Taj proces iseljavanja bitno je utjecao na kasnije kretanje broja stanovnika Boke, pa i na obilježje njegova etničkog sastava, a naročito na smanjenje udjela bokeljskih Hrvata.

\section{NASELJENOST I NASELJA}

Prvi potpuni austrijski popis stanovništva iz 1880. g. proveden je na osnovi administrativne podjele prema kojoj je Dalmacija, a koje je Boka bila dio, bila podijeljena u kotare, sudbene okruge i političke općine.

Na teritoriju kotara Kotor bilo je 12 općina, čija je ukupna površina iznosila 294,78 $\mathrm{km}^{2}$. One su bile raspoređene u sklopu triju sudbenih okruga, i to Sudbenog okruga Herceg Novi, Sudbenog okruga Kotor i Sudbenog okruga Risan (tri općine Sudbenog okruga Budva, koje su bile dio kotara Kotor, nisu uključena u ovo razmatranje). U popisu su zabilježena tri grada (Herceg Novi, Kotor i Perast s ukupno 4.737 stanovnika), četiri trgovišta (Dobrota, Prčanj, Stoliv i Risan, s ukupno 3.306 stanovnika) i 52 sela s 394 dijelova tih sela (zaselaka, skupina kuća, pojedinačnih kuća) s ukupno 22.634 stanovnika. Ukupno je, dakle, u tom području 1880. g. popisano 30.677 stanovnika .

Prevladavala su raštrkana naselja budući da je na jedno seosko naselje u prosjeku otpadalo 8 dijelova naselja, u kojima je prosječno živjelo 57 stanovnika. Navedeni oblik naseljenosti s prevladavajućim malim seoskim naseljima koja imaju veliki broj dijelova, posljedica je razlika u litostratigrafskom sastavu razmatranog prostora. Naselja uz obalu najčešće su vezana uz zone mekšeg i za poljoprivrednu obradu povoljnijeg fliša, koji je obično razvijen duž zone dodira priobalja i okolnog, reljefno višeg terena. Ta su naselja u pravilu jače okupljena i imaju više stanovnika od prosjeka za čitavo razmatrano područje. 
Ivan Crkvenčić, Antun Schaller - Boka Kotorska: društveno-političke promjene i razvoj etničkog sastava do 1918. godine

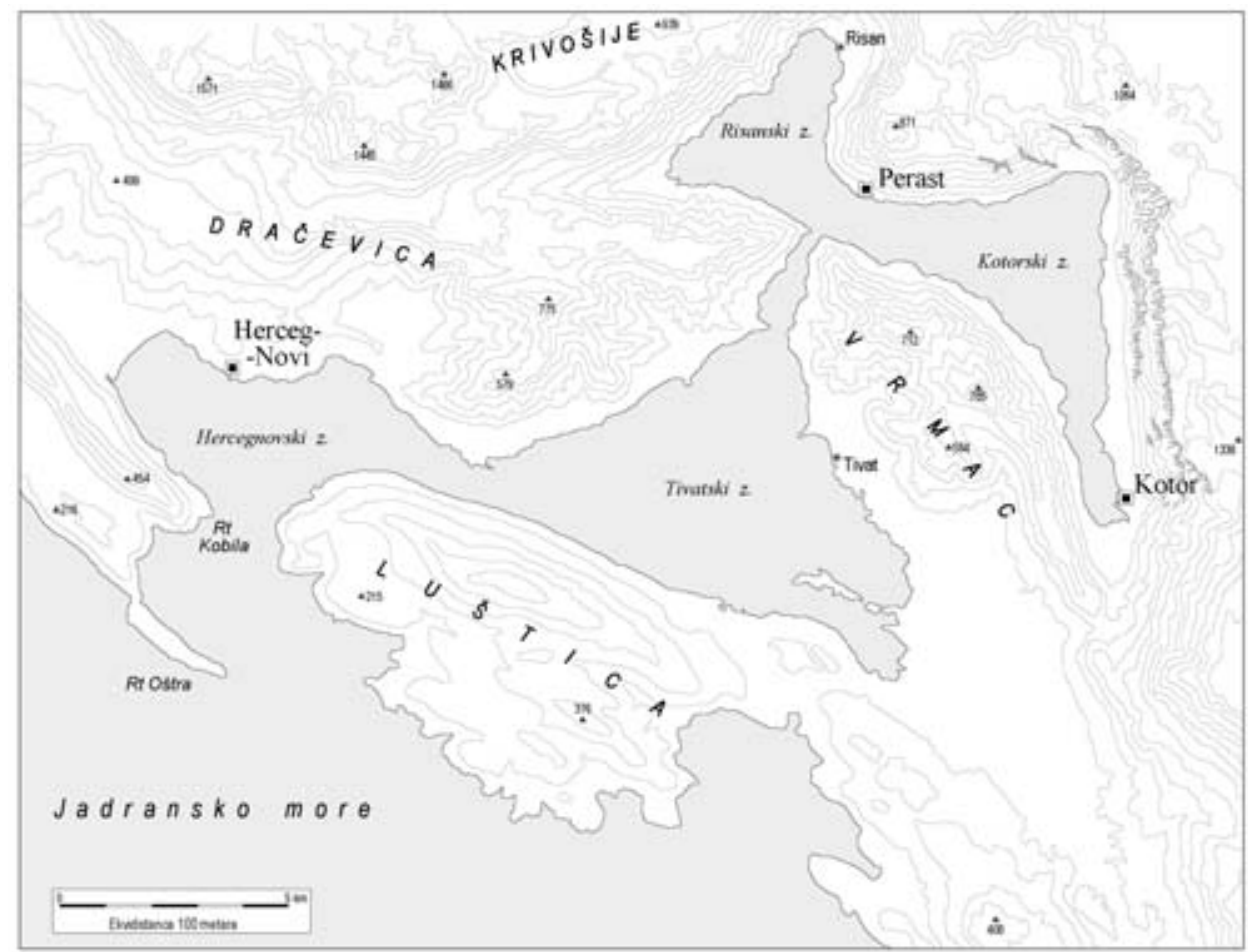

S1. 2. Boka Kotorska s gradskim naseljima i naseljima Risan i Tivat.

Fig. 2 The Boka Kotorska (Bay of Kotor) with the urban settlements and the settlements of Risan and Tivat

Naselja smještena podalje od obale više su raštrkana, i to stoga što su njihovi pojedini dijelovi vezani uz manje i prostorno međusobno odvojene obradive površine. U zoni trijaskih vapnenaca i dolomita, koji prevladavaju na padinama Risansko-kotorskog zaljeva, uglavnom su to manja udubljenja na čijem je dnu razvijena ili crvenica (nastala otapanjem vapnenca) ili pak rastresiti materijal snešen s okolnih viših područja (Milojević, B. Ž., 1953). Suprotno tome, rubne planinske padine Hercegnovsko- tivatskog zaljeva uglavnom su građene od relativno mlađih flišnih (eocen, oligocen ) ili flišovitih (malm) stijena. Te su stijene, u odnosu na vapnenačko-dolomitski sastav, relativno povoljnije za poljoprivredno iskorištavanje, a time i za naseljavanje. One izgrađuju znatan dio planinskog zaleđa Herceg Novog (Dračevica) i jugozapadni dio poluotoka Vrmac.

Važno je napomenuti da su naselja nastala na većim nadmorskim visinama i da je takav njihov položaj dijelom posljedica navedenih razlika petrografskog sastava područja. Te su razlike utjecale na mogućnosti obrade i iskorištavanja zemljišta. Ipak, treba dodati da je takav povišeni položaj naselja posljedica i društvenih prilika (političke nesigurnosti) u doba nastajanja tih naselja.

Na najvećim visinama utvrđena su naselja u planinskom zaleđu Risna, u području Krivošija, gdje se neki dijelovi naselja nalaze i na visinama od $1.000 \mathrm{~m}$ nad morem. Najveću površinu u tom području zauzima naselje Gornje Krivošije koje je 1880. g. imalo 
712 stanovnika, naseljenih u 28 dijelova istog naselja. To znači da je u tim dijelovima naselja prosječno živjelo po 28 stanovnika. Druga veća skupina naselja na većim visinama su naselja u planinskom zaleđu Herceg Novog, u predjelu Dračevice. Tu je 1880. g. na visini od 200 do $800 \mathrm{~m}$ nad morem od ukupno 19 naselja općine Herceg Novi registrirano 8 naselja (Podi, Sasovići, Žlijeb, Kameno, Trebesin, Rateševina, Mokrine i Mojdež) s ukupno 46 dijelova naselja. U tim je naseljima tada ukupno živjelo 2.625 stanovnika ili u prosjeku 57 stanovnika po dijelu naselja. Naselja na znatnoj nadmorskoj visini (do oko $500 \mathrm{~m}$ nad morem ) postojala su i na poluotocima Vrmcu i Luštici.

Očito je da je položaj naselja na relativno velikoj nadmorskoj visini posljedica političkih uvjeta i opće nesigurnosti u vrijeme njihova nastanka, dok je raštrkanost naselja posljedica njihove ovisnosti o prostorno međusobno odvojenim obradivim površinama o kojima su u doba tradicionalnog ratarsko-stočarskog gospodarenja, ovisila.

Budući da su priobalni dijelovi svojim prirodnim obilježjima povoljniji za život, kao i da su izvori života u tim dijelovima Boke raznovrsniji, to je spuštanje stanovništva iz naselja na većim nadmorskim visinama u priobalje bio stalan proces. Međutim, očito je da je taj proces prvenstveno bio uzrokovan napuštanjem tradicionalne poljoprivrede $i$ prelaskom stanovništva na bavljenje pomorstvom i pomorskom trgovinom. U tom smislu slijedi nekoliko primjera opisanog spuštanja stanovništva iz naselja na većim nadmorskim visinama u priobalje.

Današnja relativno velika naselja uz sjevernu obalu Hercegnovskog zaljeva Igalo, Meljine i Zelenika u vrijeme sva četiri austrijska popisa u drugoj polovici 19. stoljeća bila su dijelovi (s malim brojem stanovnika) naselja smještenih podalje od obale, u brdovitom zaleđu. Igalo je bilo dio naselja Topla, Meljine naselja Podi, a Zelenika naselja Kuti. Na tom dijelu obale ima još naselja koja su nastala kao rezultat spuštanja stanovnika iz planinskog zaleđa. Još bolji primjer spuštanja stanovništva na obalu su naselja Donji Stoliv i Donja Lastva, na obali poluotoka Vrmca. Svoju današnju veličinu ta su naselja dobila spuštanjem stanovništva iz njihovih prvotnih jezgri (Gornji Stoliv i Gornja Lastva), smještenih u višim dijelovima padina (visine od oko 500 m nad morem) poluotoka Vrmac. Danas su ta planinska naselja gotovo opustjela, dok je u Donjoj Lastvi 2003. g. živjelo čak 733 stanovnika. O značaju tih nekadašnjih naselja na većim nadmorskim visinama jasno govori podatak da je Gornji Stoliv u vrijeme austrijske uprave bio sjedište općine.

Dobar primjer spuštanja stanovništva s višim dijelova padina prema obali je nastanak novog naselja Tivat. Nakon što su Austrijanci Boku pretvorili u ratnu luku, na jugozapadnoj obali poluotoka Vrmca za svoju su ratnu mornaricu sagradili vojni arsenal. Time je započeo razvoj novog naselja Tivta, čija se stara jezgra (Crni Plat) nalazila u brdskom zaleđu Vrmca, na visini 150-200 m nad morem. U Tivat se postupno spustio velik broj stanovnika ne samo iz Crnog Plata, već i iz drugih naselja planinskog prostora Vrmca (Bogdašići, Kavač i dr.), pa se u Tivtu do 1910. g. broj stanovnika povećao na 1.882 osobe, od kojih je njih 715 bilo vojno osoblje, a utvrđen je 251 strani državljanin. Unatoč tome, Tivat je u razdoblju austrijske vlasti zadržao status sela.

Iako je navedeno spuštanje stanovništva na obalu prvenstveno uvjetovano napuštanjem tradicionalne poljoprivrede i prelaskom na pomorstvo i pomorsku trgovinu, proces spuštanja stanovništva je bio postupan i od područja do područja događao se u različito vrijeme. 
Spomenuta obalna naselja u podnožju Vrmca počela su se razvijati tek polovicom 19. stoljeća, a od tada se u tom području nalazi tek po koji dvorac kotorske vlastele.

Ipak, nisu sva obalna naselja nastala spuštanjem stanovništva iz planinskog zaleđa. Naprotiv, u obalnom pojasu, osobito na obalama unutrašnjeg, Risansko-kotorskog zaljeva, postoji nekoliko značajnijih starijih naselja. Tu se, naime, nalaze dva (Kotor i Perast) od tri u popisu 1880. g. spomenuta gradska naselja Boke i sva četiri u istom popisu spomenuta trgovišta (Dobrota, Prčanj, Stoliv i Risan). U vanjskom dijelu Boke, tj. u Hercegnovskotivatskom zaljevu, u spomenutom je popisu 1880. g. zabilježen je samo grad - Herceg Novi. Sva su spomenuta naselja imala upravne funkcije, i to prvenstveno Kotor kao glavno administrativno središte Boke, zatim Kotor, Herceg Novi i Risan kao središta sudbenih kotara i sjedišta političkih općina. Uz njih općinska sjedišta još su bila obalna naselja Muo, Tivat, Lastva te sela Radović (za općinu Krtole), Radovanić (za općinu Luštica) i Gornji Stoliv (za općinu Stoliv).

Spomenuti gradovi i trgovišta imaju dugu i bogatu prošlost, a raspolažu i pisanim dokumentima o svojem razvoju. O njima je bilo riječi i u ovom radu, pri razmatranju razvojnih razdoblja Boke. Stoga ih ovdje samo spominjemo, a nešto više će o njima biti govora u sljedećem članku, u prikazu stanovništva gradova Boke u razdoblju austrijske uprave .

\section{IZVORI PODATAKA O BROJU STANOVNIKA}

Već u 15., 16. i 17.stoljeću Venecijanski senat je u Dalmaciju slao tzv. 'sindaci e provveditori estraordinari' da na terenu prikupljaju određene podatke. Njihovi izvještaji pohranjeni su u venecijanskim arhivima, ali su kao izvori podataka do danas ostali gotovo neiskorišteni.

O stanovništvu Boke, naročito o njezinom konfesijskom sastavu, u 17. stoljeću, dakle, u doba političke podvojenosti Boke na mletački i turski posjed, govore dva izvještaja. Prvi, koji potječe od šibenskog franjevca Mizerčića iz 1635. g., govori o broju stanovnika nekih sela Kotorske biskupije izvan područja turske okupacije (sela Mrčevac, Crni Plat, Bogdašići, Lastva, Kavač, Luštica i Krtole). Prema tom izvještaju, u spomenutim je naseljima tada živjelo ukupno 3.500 stanovnika, od kojih je 2.100 (60\% njihovog ukupnog stanovništva) bilo rimokatoličke vjeroispovijesti. Dvije godine kasnije, tj. 1637. g. splitski franjevac Santo prigodom svog prvog posjeta Barskoj biskupiji bilježi da u području Herceg Novog, Risna, Morinja, Kostanjice, Spiča i Bara ukupno živi 2.500 stanovnika, od kojih svega 880 katolika, odnosno $35 \%$ ukupnog stanovništva istog područja.

O relativno maloj zastupljenosti rimokatolika u nekim dijelovima Boke kotorske tijekom 16. i 17. stoljeća može se zaključiti i iz pisama i izvještaja koje papi šalju kotorski biskup, zadarski nadbiskup Oktavijan Garzadora, barski nadbiskup Andrija Zmajević te niz redovnika. Oni navode da u ruralnim područjima Boke kotorske živi velik broj 'shizmatika', tj pravoslavnih.

Prvi potpuniji popis u Dalmaciji je proveden krajem 18. stoljeća, odnosno pred kraj venecijanske vlasti. Taj je popis proveden 1781 . g., i to na razini gradova i općina. Popisano je ne samo stanovništvo (općine, naselja, kuće, obitelji, broj stanovnika i njihova dob, spol 
i socijalni status te vjeroispovijesti), već su prikupljeni i neki podaci u vezi poljoprivredne proizvodnje. U popisu se navodi da je u Dalmaciji tada živjelo 206.882 katolika, 52.071 pravoslavnih i 218 Židova, odnosno ukupno 269.196 stanovnika. Nažalost, u popisu se ne navodi narodnosna pripadnost stanovništva, a nije niti proveden na razini naselja.

Ni popisi s početka austrijske uprave, koja je u cjelini trajala od 1814. do 1918. g., ne daju podatke relevantne za prosuđivanje etničkog sastava i demografske strukture Dalmacije, pa tako ni Boke. Ipak, potrebno je spomenuti statističke napomene o Dalmaciji koje je 1818. g. u bečkom časopisu 'Vaterländische Blätter' objavio anonimni autor, a kasnije ih obradio i protumačio Bernard Stulli (Stulli B., 1983). U tom se izvještaju u području Boke spominju naselja Dobrota, Prčanj, Stoliv, Perast, Risan i Herceg Novi te zasebno okolica Kotora i Župa (Grbalj). Stanovništvo se jednostavno dijeli na rimokatolike i pravoslavne (Greci).

I prvi službeni austrijski popis stanovništva, proveden 1857. g., dosta je uopćen i sadržajem manjkav. Iz njega se može zaključiti samo o ukupnom broju pripadnika različitih vjeroispovijesti (rimokatolici, pravoslavni, protestanti), i to u okviru područja Herceg Novog, Kotora i Risna, kao dijelova kotara Kotor.

Potpuni popisi stanovništva na području Dalmacije, uključujući i Boku, obavljeni su tek u drugoj polovici 19. i početkom 20. stoljeća, odnosno 1880., 1890, 1900. i 1910. g. Rezultati tih popisa objavljeni su na razini naselja, općina te sudskih i administrativnih kotara. Nažalost, ni ovi popisi ne daju podatke o narodnostima, a njih je, kao što će se kasnije pokazati, gotovo nemoguće odrediti na osnovu ostalih podataka o stanovništvu iz tih istih popisa.

\section{POZIVNE BILJEŠKE}

1. Tjesnac je tako nazvan stoga što je u doba turske najezde bio zatvoren lancem (verigama) kako bi spriječio tursko brodovlje da prodre u unutrašnji zaljev Boke kotorske, na čijim se obalama nalaze tri veća naselja - Kotor, Perast i Prčanj.

2. Bokeljska mornarica je prema nekim izvorima najstarija bratovština, odnosno, cehovska udruga na istočnoj obali Jadrana, osnovana prema nekim - iako ne posve pouzdanim izvorima - još u 9. stoljeću (prema zapisu o donošenju moći sv. Tripuna, svog zaštitnika, u Kotor, a pod naslovom 'Instrumentum corporis nostri gloriosi gonfalonis sancti Tryphonis' datum osnivanja udruge trebao bi biti 13. siječnja 809. g.) (Mijušković, S., 1972). Pisani statut udruge potječe iz 1463. g. Naime, sredinom 15. stoljeća organizirali su se pomorci iz Kotora, slično kao i pripadnici drugih gospodarskih grana, u posebnu stalešku udrugu (bratovštinu, frateliju ili ceh) radi međusobnog potpomaganja i čuvanja svojih interesa pod pokroviteljstvom Crkve u bratovštinu pomoraca (confraternitas nautarum) sa sjedištem u crkvi sv. Nikole u Kotoru. Bratovštini su pripadali brodovlasnici, zapovjednici i posade brodova. Na čelu organizacije bio je gastaldus (prema langobardskom 'gastaldio' = upravitelj), tri prokuratora i dva sindika. U upravu se redovito birao i lučki admiral, koji je bio državni namještenik, imenovan na početku od mletačke vlasti, a kasnije biran od bratovštine, a potvrđen od mletačke uprave. Bratovština je potpomagala siromašne obitelji, upravljala brodogradilištima, a isticala se i pothvatima u borbama protiv Turaka. Kao cehovska udruga nositeljica je pomorskog prosperiteta Boke u razdoblju od 15. do kraja 18. stoljeća. U svom izvornom djelatnom obliku Bokeljska mornarica ukinuta je odlukom francuskih (Napoleonovih) okupacijskih vlasti 1811. g. (Primožić, A., 1942). Nakon toga, bratovština djeluje na razini nositeljice i čuvarice kulturnog nasljeđa bokeljskih pomoraca, uključujući sve one stečevine koje su Boku kao specifičan maritimni prostor tradicijski kroz povijest krasile. U tom smislu, bratovština pod nazivom "Bokeljska mornarica 809" djeluje i danas. 
Ivan Crkvenčić, Antun Schaller - Boka Kotorska: društveno-političke promjene i razvoj etničkog sastava do 1918. godine

\section{LITERATURA}

Butorac, P., 1963: Teritorijalni razvitak Kotora, Anali Historijskog instituta JAZU u Dubrovniku, god. X-XI, Dubrovnik.

Crkvenčić, I., 2000: The Posavina Border Region of Croatia and Bosnia-Herzegovina: Development up to 1918 (With Special Reference to Changes in Ethnic Composition), Društvena istraživanja 13 (2004), 1-2 (69-70): 293-314, Centra za društvena istraživanja 'Ivan Pilar', Zagreb.

Crkvenčić, I., 1996: Pepeonik, Z., Westslavonien - Entwicklung der demographischen Struktur, Südosteuropa, 36/1.

Macan, T., 1993: Pogled u bokeljsku povijest, Hrvatska revija, br. 43/1, str. 19-27, Zagreb.

Marinović, A., 1993: Boka kotorska od najstarijih vremena do početka XX. stoljeća; Dubrovnik, br. 4., str. 184 205, Matica Hrvatska - ogranak Dubrovnik, Dubrovnik.

Maschek, A., 1888: Geographisch-statistische Repertorium der bewohnten Orte im Königreiche Dalmatien, Zara.

Mijušković, S., 1972: Bokeljska mornarica u 12 vjekova Bokeljske mornarice, str. 15-33, Monos, Beograd.

Milojević, B. Ž., 1953: Boka kotorska, Zbornik radova SAN XXVII, knjiga V, Beograd.

Piplović, S., 2003: Katastar okružja Kotor iz prve polovice XIX. stoljeća, Hrvati Boke kotorske str. 91-114, posebno izdanje Zbornika pomorskog muzeja, Orebić.

Primožić, A., 1942: Bokeljska mornarica, dio predmetne jedinice 'Boka kotorska' u Hrvatskoj enciklopediji, sv. III, str. 22, Naklada Hrvatskog izdavalačkog bibliografskog zavoda, Zagreb.

Rendić-Miočević, I., 2003: Od popa Dukljanina do Baje Pivljanina u Hrvati Boke kotorske, str. 91-114, posebno izdanje Zbornika Pomorskog muzeja, Orebić.

Riđanović, J., 1990: Hidromorfološke specifičnosti Boke kotorske; Peto znanstveno posvetovanje geomorfologov Jugoslavije, Krško, 18-23. junij 1990., Zbornik referatov, str. 111-118, Ljubljana.

Riđanović J., 1993: Die Bucht von Kotor und der Meeresspiegelanstieg im Holozän, Würzburger Geographische Arbeiten, No. 87, s. 305-312, Würzburg.

Roglić, J., 1967: Prilog poznavanju reljefa jadranskog priobalnog dna, Rad JAZU, knjiga 345, str. 39-54, Zagreb.

Sindik, I., 1950: Komunalno uređenje Kotora od druge polovice 12. stoljeća do početka 15. stoljeća, SAN, Posebno izdanje, knjiga CLXV, str 38-39, Beograd.

Stulli B., 1983: Građa o stanju u Dalmaciji 1818. godine, Zbornik Zavoda za povijesne znanosti Istraživačkog centra JAZU, Vol. 13, str. 119-190, JAZU, Zagreb.

Štedimlija, S.M., 1991: Crvena Hrvatska, Laus, Biblioteka ‘Povijesnice’ br. 2, Split. 


\title{
SUMMARY
}

\section{Boka Kotorska (The Bay of Kotor): Social and Political Changes and Development of Ethnic Structure up to 1918}

\author{
By Ivan Crkvenčić and Antun Schaller
}

Boka Kotorska is a relatively large and well-indented bay lying at south of the east Adriatic coast. In political sense it is part of Montenegro, one of two republics composing the State Union of Serbia and Montenegro. The area of consideration is situated immediately at the state border to the Republic of Croatia. It is a specific geographical entity, characterised by a very complex process of social development and consequent ethnic changes. In spite of that, Boka Kotorska is recognisable by its unique cultural landscape, which has been formed during centuries of its abundant history. These characteristics of Boka Kotorska are considerably caused by: (1) peculiarities of its shape and nature, (2) its geopolitical position at south of east Adriatic coast, which had for a long time been exposed to foreign political influences from both maritime and continental (inland) sides, (3) contact position of Boka Kotorska between traditional areas of predominant Catholic at one, and Orthodox confession and culture at the other side, which were later differentiated into Croatian and Serbian-Montenegrin territories, respectively, and (4) the invasion of Turks into the hinterland and, subsequently (in $15^{\text {th }}$ century) also to the parts of Boka Kotorska shoreline itself, causing major suffer and migrations, as well as spread-out of Islamic faith, particularly for account of Catholics.

Three significant periods of the past of Boka Kotorska, i.e. pre-Venice, Venice-Turkish and Austrian, are described in the paper. A special consideration is dedicated to those elements showing out the external political links of Boka Kotorska, but also to the historic facts which were considerably important for development of ethnic structure of the area. Changes of ethnic composition of the population living in Boka Kotorska as well as corresponding settlement patterns of the area are also elaborated in the paper.

Primljeno (Received): 11 - 05 - 2005

Prihvaćeno (Accepted): 25 - 10 - 2005

dr. sci. Ivan Crkvenčić, profesor emeritus, Geografski odsjek PMF-a, Marulićev trg 19, 10 000, Zagreb, Hrvatska/Croatia

mr. sci. Antun Schaller, dipl. ing., APO d.o.o., Zagreb 